\title{
Production and Purification of the Gamma Haemolysin of Staphylococcus aureus 'Smith 5R'
}

\author{
By H. B. FACKRELL* AND G. M. WISEMAN \\ Department of Medical Microbiology, University of Manitoba, \\ Winnipeg, Canada
}

(Received 25 January 1974; revised 30 June 1975)

SUMMARY

The gamma haemolysin of Staphylococcus aureus 'Smith 5R' was produced on Dolman-Wilson agar overlain with cellophane. Maximal yields of crude lysin with titres of 2000 to 4000 haemolytic units/ml were obtained within $24 \mathrm{~h}$ at $37^{\circ} \mathrm{C}$ in $10 \%(\mathrm{v} / \mathrm{v}) \mathrm{CO}_{2}$ in air, on medium adjusted to $\mathrm{pH} 7.0$.

The crude lysin was purified 2700 -fold (with $75 \%$ recovery) by ultrafiltration, gel filtration and ammonium sulphate fractionation. The specific activity of the lysin was $10^{5}$ haemolytic units/mg protein after the dialysed active precipitate was extracted with $\mathrm{NaCl}$ and reprecipitated with ammonium sulphate. Purified gamma lysin was homogeneous by disc electrophoresis and immunoelectrophoresis.

\section{INTRODUCTION}

The existence of gamma haemolysin was first reported by Smith \& Price (1938) in their investigation of some strains of Staphylococcus aureus. These observations were confirmed by Marks (195I) who agreed that the gamma lysin was distinct from the alpha, beta and delta lysins. Elek (1959) was of the opinion that the existence of gamma lysin had not been proved since its presence was not demonstrated in his antitoxin-blood agar plate test. However, agar is now known to inhibit the activity of the gamma lysin (Jackson, 1962; Guyonnet \& Plommet, 1970; Mollby \& Wadstrom, 1971; Fackrell, 1974).

Production and purification of the gamma lysin have been described by Plommet \& Bouillanne (1966) and by Mollby \& Wadstrom (1971). We have not been able to produce gamma lysin by the method of Plommet and Bouillanne and have found that the Mollby and Wadstrom procedure yields a preparation of very low titre.

The present paper describes a method of production and purification of gamma lysin which results in higher yields of material which have a high specific activity.

\section{METHODS}

The 'Smith 5R' strain of Staphylococcus aureus used for the production of gamma lysin was obtained from Dr F. Guyonnet. The organism was subcultured once monthly on brain-heart infusion agar (Difco) slants incubated at $37^{\circ} \mathrm{C}$ for $24 \mathrm{~h}$ and stored at $4{ }^{\circ} \mathrm{C}$.

Growth was determined routinely by a procedure in which bacterial cultures were diluted I: 20 with phosphate buffered saline, after which the $E_{650}$ of the diluted suspension was determined in a SP 800 B double beam recording spectrophotometer (Pye Unicam, Cambridge). Viable counts, when required, were determined by the standard pour plate method on Dolman-Wilson agar (Dolman \& Wilson, 1940).

- Present address: Department of Biology, University of Windsor, Windsor, Ontario, Canada. 
Haemolytic titrations of gamma lysin were performed with human red cells as described by Wiseman \& Caird (1972). Human blood $\left(\mathrm{Rh}^{+}\right.$, group $\mathrm{O}$ ) obtained from the Canadian Red Cross in Winnipeg was stored in acid-citrate-dextrose solution as supplied.

Proteolytic activity of cultures in some experiments was determined as described by Wiseman \& Caird (1972).

Gel filtration of gamma lysin was performed in $5 \times 100 \mathrm{~cm}$ columns of Sephadex (various grades) suspended in phosphate buffer $\mathrm{pH} 7.0$ which contained $0.5 \mathrm{M}-\mathrm{NaCl}$. The column packing procedure was that described by the manufacturer (Pharmacia). Volumes of to to I $5 \mathrm{ml}$ were collected by upward elution.

The technique of Birch-Hirschfeld (1934) was applied to the production of crude gamma lysin by the Smith $5 \mathrm{R}$ strain. Difco agar ( $1 \cdot 5 \%$, w/v) was added to $500 \mathrm{ml}$ quantities of Dolman-Wilson broth and the autoclaved medium poured into sterile stainless steel trays $1800 \mathrm{~cm}^{2}$ in area. After cooling, the solidified medium was overlaid with cellophane (Dennison Mfg, Drummondville, Quebec, Canada; no. 5700I) which had been sterilized by immersion in water and exposure to steam for $\mathbf{I} h$.

The inoculum was prepared from slants of $16 \mathrm{~h}$ cultures to which were added $5 \mathrm{ml}$ of sterile phosphate buffered saline, and the contents distributed over the surface of the cellophane with a glass spreader. The trays were covered, placed in Perspex boxes and flushed with $10 \%(\mathrm{v} / \mathrm{v}) \mathrm{CO}_{2}$ in air at a rate of $20 \mathrm{l} / \mathrm{min}$ for $10 \mathrm{~min}$ before being incubated at $37^{\circ} \mathrm{C}$ for $24 \mathrm{~h}$. At the end of the period, the trays were removed and the cellophane flooded with $50 \mathrm{ml}$ of phosphate buffered saline. The bacteria were suspended with a bent glass rod, removed and centrifuged at $10000 \mathrm{~g}$ for $15 \mathrm{~min}$. The supernatant fluid, which contained crude gamma lysin, was retained and stored at $-20^{\circ} \mathrm{C}$. Because of technical difficulties, some experiments required that small Petri dishes rather than the large trays be used, and medium and volumes were then decreased proportionally.

Antibodies to gamma lysin were prepared in New Zealand white rabbits as described for alpha lysin by Wiseman, Caird \& Fackrell (I974). Before use, antisera were purified by the method of Campbell et al. (I970). Immunodiffusion and immunoelectrophoresis were performed according to methods described by these authors.

Buffers were prepared according to Gomori (1955). Phosphate-saline buffer (0.01 M, $\mathrm{pH} 7 \cdot 0$ ) was used as a general diluent, and contained $\mathrm{NaCl}$ at a concentration of $0.15 \mathrm{M}$; in some experiments phosphate buffer which contained other concentrations of $\mathrm{NaCl}$ was required.

Protein in column effluents was expressed in terms of $E_{280}$. Otherwise, the micro-Kjeldahl technique described by Markham (1942) was used to assay nitrogen, and the value was multiplied by $6 \cdot 25$ as an estimate of the protein content of the sample.

Polyacrylamide disc gel electrophoresis used in the characterization of gamma lysin has been described elsewhere (Wiseman et al. 1974).

\section{RESULTS}

\section{Production of gamma lysin}

No haemolysin was produced on semi-solid or solid media, although good growth was obtained (Table I). Some lysin was produced in liquid media, presumably because of the absence of agar, but titres were low. Haemolysin was measured in haemolytic units (h.u.)/ml.

The Birch-Hirschfeld technique, described in Methods, was used with ten varieties of solid media. The highest yields of haemolysin were obtained with Dolman-Wilson and 
Table I. Growth and haemolysin production on liquid, semi-solid and solid media

\begin{tabular}{|c|c|c|}
\hline Medium & $\begin{array}{c}\text { Growth } \\
\left(E_{\text {os0 }}\right)\end{array}$ & $\begin{array}{c}\text { Haemolysin } \\
\text { titre } \\
\text { (h.u./ml) }\end{array}$ \\
\hline \multicolumn{3}{|l|}{ Liquid medium } \\
\hline Dolman-Wilson (1940) & 0.51 & 78 \\
\hline Gladstone \& van Heyningen (1957) & 0.11 & 0 \\
\hline Stolp \& Petzold (1962) & 0.24 & 13 \\
\hline Brain-heart infusion & 0.48 & 23 \\
\hline \multicolumn{3}{|l|}{ Semi-solid medium* } \\
\hline Dolman-Wilson & 0.55 & 0 \\
\hline Gladstonè \& van Heyningen & 0.35 & 0 \\
\hline Stolp \& Petzold & 0.30 & 0 \\
\hline Brain-heart infusion & 0.45 & 0 \\
\hline \multicolumn{3}{|l|}{ Solid medium* } \\
\hline Dolman-Wilson & 0.63 & 0 \\
\hline Gladstone \& van Heyningen & 0.59 & 0 \\
\hline Stolp \& Pretzold & 0.52 & 0 \\
\hline Brain-heart infusion & 0.40 & 0 \\
\hline
\end{tabular}

* The lysin was extracted from the agar by freezing and thawing the medium 4 or 5 times and then centrifuging the liquid that was produced. The supernatant fluid was assayed for haemolysin. Growth in semi-solid and solid media was measured by melting the agar before dilution with buffered saline.

\section{Table 2. Gamma haemolysin production on different media}

Solid medium was overlain with sterile cellophane, inoculated, and incubated for $24 \mathrm{~h}$ at $37^{\circ} \mathrm{C}$ in $10 \%(\mathrm{v} / \mathrm{v}) \mathrm{CO}_{2}$. The bacteria were suspended in $2 \cdot 2 \mathrm{ml}$ buffer and scraped off; $0.2 \mathrm{ml}$ of suspension was added to $3.8 \mathrm{ml}$ of buffered saline, and the $E_{\text {eso }}$ was used as an index of growth. The rest of the suspension was centrifuged to remove bacteria and the supernatant liquid assayed for haemolysin.

\begin{tabular}{lcc}
\multicolumn{1}{c}{ Medium } & $\begin{array}{c}\text { Growth } \\
\left(E_{\text {oso }}\right)\end{array}$ & $\begin{array}{c}\text { Haemolysin } \\
\text { titre } \\
\text { (h.u./ml } \pm \text { S.E.M. })\end{array}$ \\
Dolman-Wilson & 0.810 & $453 \pm 21$ \\
Gladstone \& van Heyningen & 0.850 & $441 \pm 27$ \\
Brain-heart infusion* & 0.650 & $263 \pm 14$ \\
Veal infusion* & 0.710 & $205 \pm 20$ \\
Liver infusion* & 0.790 & $152 \pm 10$ \\
Stolp \& Petzold & 0.516 & $136 \pm 9$ \\
Blood agar* & 0.610 & $86 \pm 6$ \\
Trypticase soy* & 0.492 & $30 \pm 2$ \\
Nutrient agar* & 0.320 & $15 \pm 1$ \\
Casamino acids* & 0.116 & $6 \pm 1$
\end{tabular}

* Obtained from Difco.

Gladstone \& van Heyningen (1957) media (Table 2). The former medium was easy to prepare and was used subsequently. There was a direct correlation between growth and lysin formation.

Organisms were grown for various times to determine the incubation period corresponding to the highest yield of lysin. The haemolysin samples were stored at $-20^{\circ} \mathrm{C}$ until required and then all were titrated against the same sample of blood. Gamma lysin produced on Dolman-Wilson medium reached a maximum titre after $24 \mathrm{~h}$ incubation, at the end of the exponential phase of growth (Fig. I). Maximum growth was not reached for $48 \mathrm{~h}$, but by this time only $15 \%$ of the total haemolytic activity demonstrable at $24 \mathrm{~h}$ remained. 


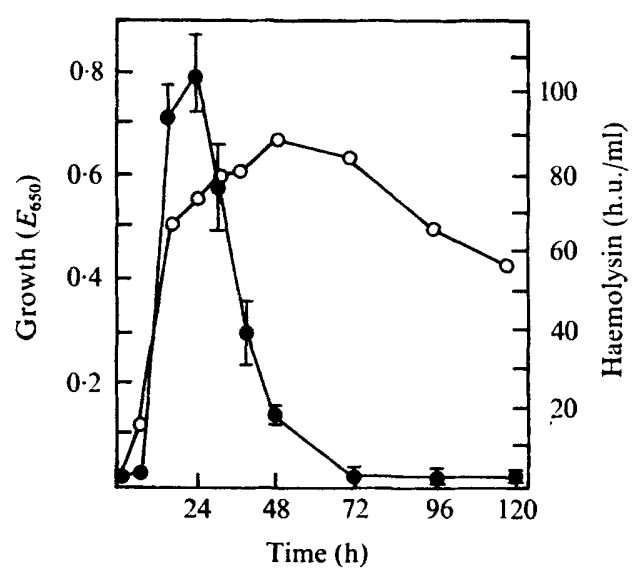

Fig. I. Effect of incubation time on production of gamma lysin by the Smith $5 R$ strain. Organisms were inoculated on the surface of Dolman-Wilson agar overlain with sterile cellophane and incubated at $37^{\circ} \mathrm{C}$ in $10 \%(v / v) \mathrm{CO}_{2}$ for varying intervals. $\mathrm{O}$, Growth; 0 , haemolysin titre. The bars, in this and subsequent Figures, indicate the range of values obtained.
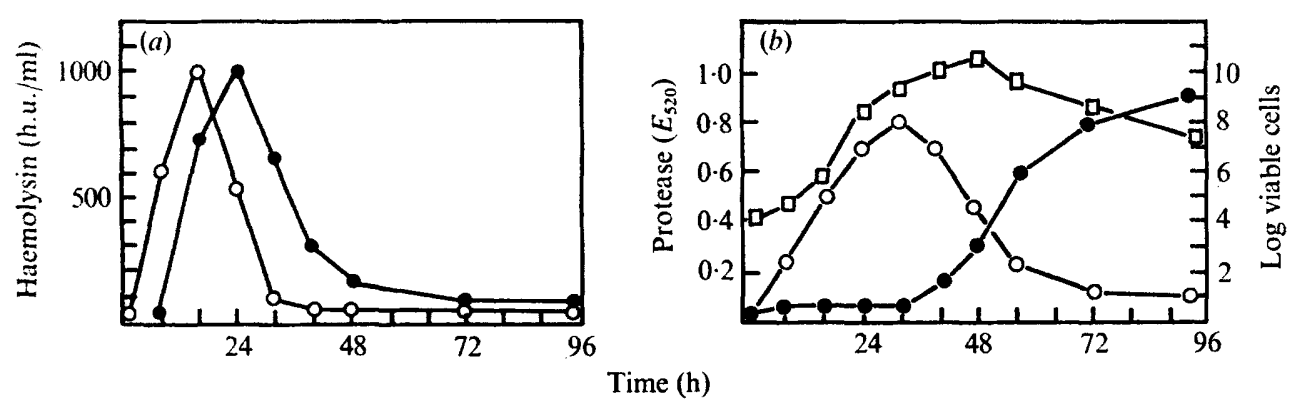

Fig. 2. Production of intracellular and extracellular gamma lysin by the Smith $5 R$ strain. The experiment is similar to Fig. I except the suspension was centrifuged to separate bacteria from a supernatant liquid containing extracellular gamma lysin. The bacteria were washed with buffer and incubated with Lysostaphin (see text) to cause lysis and release of intracellular lysin. $(a) O$, Intracellular lysin; $\bigcirc$, extracellular lysin. (b) $\bigcirc$, Intracellular protease; $\bigcirc$, extracellular proteins; $\square$, colony forming units.

The rapid appearance of gamma lysin during the exponential phase of growth suggested that it may be an extracellular product. Organisms of the Smith $5 R$ strain were centrifuged and washed twice in phosphate buffered saline. Both the supernatant liquid and the washed bacteria were incubated with Lysostaphin ( $\mathrm{I} \mathrm{mg} / \mathrm{ml}$; Mead-Johnson Co., Evansville, Indiana, U.S.A.) for $15 \mathrm{~min}$ at $37^{\circ} \mathrm{C}$ and the fluid was then assayed for haemolytic and proteolytic activity. Proteolysis was used as an indicator of autolysis because the Smith $5 \mathrm{R}$ strain appeared to produce no extracellular protease until very late in batch growth. Intracellular haemolysin in the washed pellet was detected after $8 \mathrm{~h}$ (Fig. 2) and reached a maximum at $16 \mathrm{~h}$, in contrast with the extracellular haemolysin in the supernatant liquid which reached its highest levels after $24 \mathrm{~h}$ (Fig. I). Although protease was present intracellularly, it did not appear in the supernatant liquid until $40 \mathrm{~h}$ had elapsed, which suggests that the cytoplasmic membrane was intact when gamma lysin was released into the medium.

The Smith 5R strain grew well over an initial $\mathrm{pH}$ range of 5.0 to $8 \cdot 5$ (Fig .3 ) but maximum 


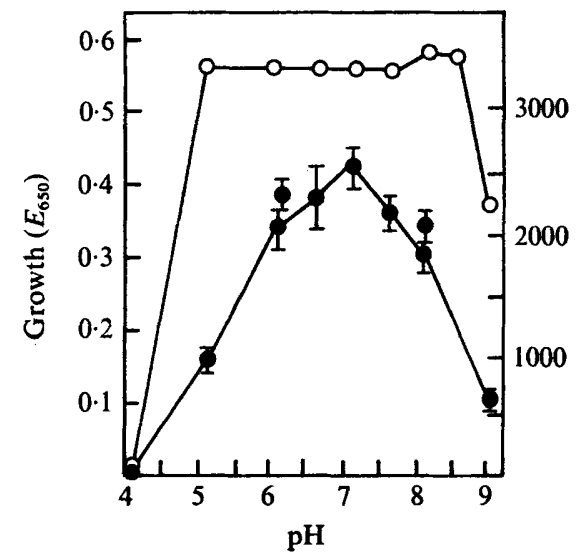

Fig. 3

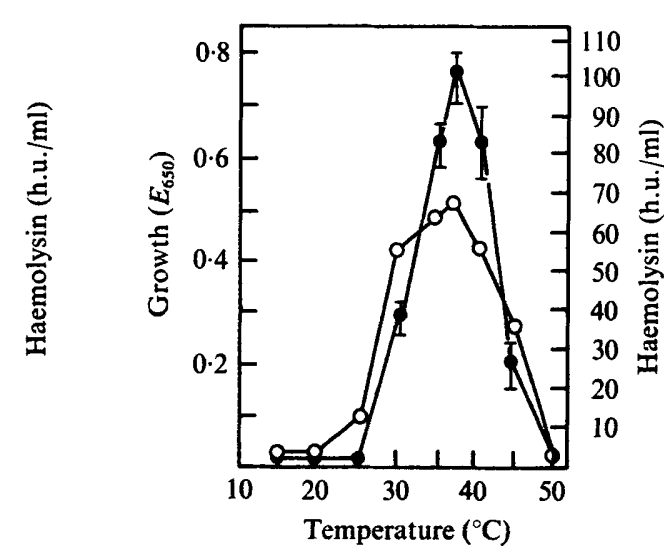

Fig. 4

Fig. 3. The effect of $\mathbf{p H}$ on production of gamma lysin by the Smith $5 \mathrm{R}$ strain. Organisms were grown on Dolman-Wilson agar overlain with sterile cellophane (see text) for $24 \mathrm{~h}$ in an atmosphere of $10 \%(\mathrm{v} / \mathrm{v}) \mathrm{CO}_{2}$. O, Haemolysin titres; $\mathrm{O}$, growth. pH 4 to 6 , succinate buffer; pH 6 to 8 , phosphate buffer; $\mathrm{pH} 8$ to 9 , tris- $\mathbf{H C l}$ buffer.

Fig. 4. Effect of temperature on growth and gamma lysin production by the Smith $\mathbf{5 R}$ strain. Bacteria were incubated for $24 \mathrm{~h}$ on Dolman-Wilson agar in an atmosphere of $\mathrm{CO}_{2}$. Haemolysin titres; O, growth.

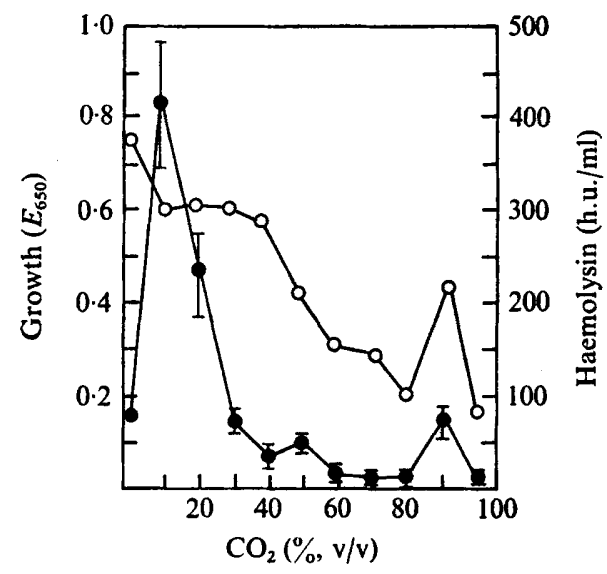

Fig. 5

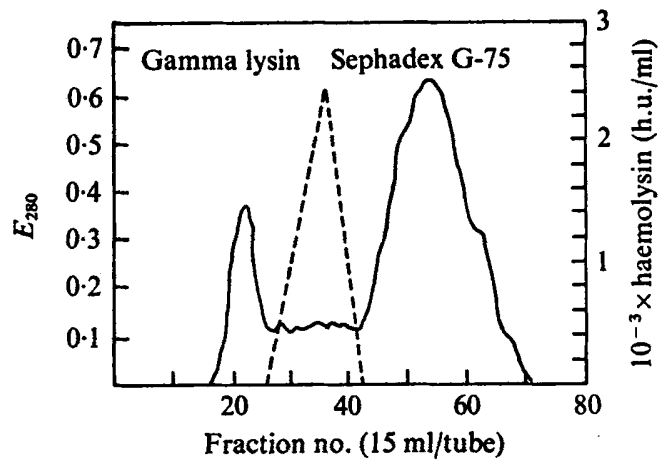

Fig. 6

Fig. 5. The effect of carbon dioxide concentration upon gamma lysin production by the Smith $5 R$ strain. Bacteria were incubated on Dolman-Wilson agar as described, for $24 \mathrm{~h}$ at $37^{\circ} \mathrm{C}$. $\mathrm{O}$, Haemolysin titres; $O$, growth.

Fig. 6. Gel filtration of Smith 5R gamma lysin on Sephadex G-75 eluted with 0.05 M-phosphate buffer $\mathrm{pH} 7 \cdot 0+0.5 \mathrm{M}-\mathrm{NaCl}$. From $\mathrm{I} \times 10^{5}$ to $\mathrm{I} \cdot 5 \times 10^{5} \mathrm{~h}$.u. were applied to the column and recovery ranged from 85 to $100 \%$. - - , Haemolysin titres; - extinction.

titres of lysin were produced at $\mathrm{pH} 7 \cdot 0$. The buffer salts used in this experiment had no effect upon haemolysin, i.e. they neither enhanced nor inhibited its activity since haemolysin dialysed against various buffer components at the same $\mathrm{pH}$ value gave similar levels of activity. In another experiment, crude lysin was dialysed against buffers of $\mathrm{pH}$ values 4.0 to 9.5 , but retained all of its activity even after storage for 4 to 6 weeks at $4{ }^{\circ} \mathrm{C}$. However, 
Table 3. Ultrafiltration of gamma haemolysin

\begin{tabular}{|c|c|c|c|c|}
\hline Membrane & $\begin{array}{c}\text { Total } \\
\text { haemolysin } \\
\text { (h.u.) }\end{array}$ & $\begin{array}{l}\text { Total } \\
\text { protein } \\
\text { (mg) }\end{array}$ & $\begin{array}{c}\text { Specific } \\
\text { activity } \\
\text { (h.u./mg) }\end{array}$ & Purification \\
\hline None & 125000 & 90 & 1400 & $\times I \cdot 0$ \\
\hline $\begin{array}{l}\text { UM-10 } \\
\text { Retained } \\
\text { Passed }\end{array}$ & $\begin{array}{r}125000 \\
0\end{array}$ & $\begin{array}{l}64 \\
15\end{array}$ & $\begin{array}{c}2000 \\
-\end{array}$ & $\times 1 \cdot 4$ \\
\hline $\begin{array}{l}\text { PM-30 } \\
\text { Retained } \\
\text { Passed }\end{array}$ & $\begin{array}{r}125000 \\
0\end{array}$ & $\begin{array}{l}62 \\
14\end{array}$ & 2000 & $\begin{array}{l}\times 1 \cdot 4 \\
-\end{array}$ \\
\hline $\begin{array}{l}\text { XM-50 } \\
\text { Retained } \\
\text { Passed }\end{array}$ & $\begin{array}{r}125000 \\
0\end{array}$ & $\begin{array}{l}31 \\
56\end{array}$ & $\begin{array}{c}4000 \\
-\end{array}$ & $\begin{array}{c}\times 2.9 \\
-\end{array}$ \\
\hline $\begin{array}{l}\text { XM-1 } \infty \\
\text { Retained } \\
\text { Passed }\end{array}$ & $\begin{array}{l}35000 \\
90000\end{array}$ & $\begin{array}{l}17 \\
66\end{array}$ & $\begin{array}{l}2000 \\
1400\end{array}$ & $\begin{array}{l}\times 1.4 \\
\times 0.0\end{array}$ \\
\hline
\end{tabular}

crude lysin was rapidly destroyed by exposure to $\mathrm{pH}$ levels below 3.5 or above $10 \cdot 0$ (results not shown).

Temperature influenced both growth and haemolysin production (Fig. 4). Maximal haemolysin production and growth occurred at $37^{\circ} \mathrm{C}$, but a shift of $3{ }^{\circ} \mathrm{C}$ from this temperature resulted in a decrease in the amount of haemolysin found in the supernatant liquid. No haemolysin was detected at 25 or $50^{\circ} \mathrm{C}$ although slight growth occurred at $25^{\circ} \mathrm{C}$.

Petri dishes were inoculated and placed in anaerobic jars, flushed with a range of mixtures of $\mathrm{CO}_{2}$ in air, then sealed and incubated at $37^{\circ} \mathrm{C}$ for $24 \mathrm{~h}$. Carbon dioxide concentration was measured at low levels with a 'Kwik-Chek' carbon dioxide analyser (Burrell Corp., Pittsburgh, Pennsylvania, U.S.A.). The production of gamma lysin showed a marked dependence upon $\mathrm{CO}_{2}$ tension (Fig. 5) with maximum yields of the lysin being achieved in an atmosphere of $10 \%(\mathrm{v} / \mathrm{v})$ of the gas. Growth gradually decreased at higher concentrations of $\mathrm{CO}_{2}$ but an increase in growth was observed repeatedly at $90 \%(\mathrm{v} / \mathrm{v})$ levels. Maximum growth occurred in air alone but the greatest amounts of haemolysin were formed in $10 \%$ (v/v) $\mathrm{CO}_{2}$.

It seemed possible that dissolved carbon dioxide at higher concentrations might have decreased the amount of haemolysin formed by changing the $\mathrm{pH}$ of the medium. In another experiment, however, $\mathrm{pH}$ remained constant in well-buffered media over the range of $\mathrm{CO}_{2}$ tensions tested (results not shown).

\section{Purification of gamma haemolysin}

A series of Amicon membranes (Amicon Corp., Cambridge, Massachusetts, U.S.A.), UM-10, PM-30, XM-50 and XM-roo, was tested for its ability to concentrate and purify gamma lysin. Ten $\mathrm{ml}$ of the lysin were concentrated to one $\mathrm{ml}$ and diluted to $10 \mathrm{ml}$; this procedure was repeated three times so that all lysin capable of traversing the membranes was removed. Both the retained material and the filtered fraction were assayed for gamma lysin and protein. Haemolysin was completely retained by UM-10, PM-30 and XM-50 membranes but passed through the XM-Ioo membrane (Table 3). A threefold increase in specific activity was observed with the XM-50 membrane and the haemolysin was concentrated ro- to 20-fold. Consequently, filtration by this membrane was used as the first step in purification of gamma lysin. 
Table 4. Ammonium sulphate fractionation of gamma haemolysin

$\begin{array}{ccccc}\begin{array}{c}\text { Ammonium } \\ \text { sulphate* } \\ \text { (\% saturation) }\end{array} & \begin{array}{c}\text { Total } \\ \text { haemolysin in } \\ \text { precipitate } \\ \text { (h.u.) }\end{array} & \begin{array}{c}\text { Total } \\ \text { protein in } \\ \text { precipitate } \\ \text { (mg) }\end{array} & \begin{array}{c}\text { Specific } \\ \text { activity } \\ \text { (h.u./mg) }\end{array} & \text { Purification } \\ \text { Not treated } & 4800 & 2.220 & 2162 & \times 1 \cdot 0 \\ 15 & 0 & 0.205 & - & - \\ 30 & 2200 & 0.325 & 6769 & \times 3 \cdot 1 \\ 45 & 3500 & 0.480 & 7291 & \times 3.4 \\ 60 & 4300 & 0.510 & 8431 & \times 3.9 \\ 75 & 4400 & 1 \cdot 100 & 4000 & \times 1 \cdot 9 \\ 90 & 4300 & 1 \cdot 790 & 2402 & \times 1 \cdot 1 \\ 100 & 4500 & 2.010 & 2238 & \times 1 \cdot 0\end{array}$

* The effluent from a Sephadex G-75 column was divided into eight equal parts and each received an amount of ammonium sulphate as indicated in the Table.

Sephadex gel filtration was then investigated as a second step in the purification procedure. In a series of preliminary experiments, gamma lysin concentrated by ultrafiltration was fractionated on columns which contained G-50, G-75, G-100 or G-200 gels. The best increase in specific activity with $100 \%$ recovery was obtained with Sephadex G-75, and this method was subsequently used; gamma lysin $\left(V_{\mathrm{e}} / V_{\mathrm{o}}=\mathrm{I} \cdot 45\right)$ appeared in the effluent between two major protein peaks (Fig. 6).

Ammonium sulphate fractionation was the third step in the purification procedure. Pooled active fractions obtained from the Sephadex G-75 column were divided into several parts and increased amounts of ammonium sulphate were added to each. The precipitate, after standing overnight at $4{ }^{\circ} \mathrm{C}$, was centrifuged and resuspended, then dialysed against phosphate-buffered saline and titrated for haemolysin and protein content. About $95 \%$ of the haemolysin was recovered in the precipitate of the fraction with $60 \%$ ammonium sulphate saturation (Table 4 ), with a resulting increase in specific activity to 8431 haemolytic units/mg. Higher concentrations of ammonium sulphate caused precipitation of contaminating proteins. Subsequent experiments (not shown) demonstrated that no gamma lysin was precipitated by $25 \%$ ammonium sulphate. To summarize, ammonium sulphate to $25 \%$ saturation was added to haemolysin eluted from a Sephadex G-75 column and this precipitate was discarded. More of the salt was added to give a final concentration of $60 \%$ saturation and this second precipitate which contained the lysin was collected.

Gamma lysin fractionated by ammonium sulphate could be dissolved by dialysis against phosphate-buffered saline. Subsequent dialysis of the dissolved lysin against distilled water caused the formation of a white precipitate and loss of haemolytic activity. If dissolved lysin, which contained protein, phosphate and pentose, was treated with ribonuclease $(50 \mu \mathrm{g} / \mathrm{ml})$ at $37^{\circ} \mathrm{C}, \mathrm{pH} 7.0$ for $\mathrm{I} \mathrm{h}$ and then dialysed against distilled water, the amount of precipitate was much less and contained only protein. This finding suggested that gamma lysin was co-precipitated with nucleic acids. Since nucleic acids are irreversibly denatured by dialysis against distilled water, an attempt was made selectively to dissolve the precipitated gamma lysin with $\mathrm{NaCl}$.

After fractionation with ammonium sulphate, gamma lysin was dialysed against distilled water for three days and various concentrations of $\mathrm{NaCl}$ in $0.01 \mathrm{M}$-phosphate buffer were added to suspensions of the precipitate. The treated suspensions were centrifuged to separate the insoluble material from the supernatant fluids. The insoluble pellet was then washed with $2.0 \mathrm{M}-\mathrm{NaCl}$. Finally, both pellet and supernatant liquid were assayed for 
Table 5. Dialysis and salt extraction of gamma haemolysin

The $\mathrm{NaCl}$ was in o.or $\mathrm{M}$-phosphate buffer except where stated.

$\begin{array}{lcccc}\begin{array}{c}\text { NaCl } \\ \text { (M) }\end{array} & \begin{array}{c}\text { Haemolysin } \\ \text { (h.u./ml) }\end{array} & \begin{array}{c}\text { Protein } \\ (\mathrm{mg} / \mathrm{ml})\end{array} & \begin{array}{c}\text { Haemolysin } \\ \text { (h.u./ml) }\end{array} & \begin{array}{c}\text { Protein } \\ (\mathrm{mg} / \mathrm{ml})\end{array} \\ 0^{*} & 0 & 0.045 & 1300 & 0.305 \\ 0 & 270 & 0.104 & 990 & 0.245 \\ 0.01 & 320 & 0.130 & 880 & 0.225 \\ 0.03 & 470 & 0.135 & 795 & 0.230 \\ 0.06 & 520 & 0.140 & 630 & 0.218 \\ 0.10 & 640 & 0.150 & 510 & 0.205 \\ 0.30 & 970 & 0.154 & 275 & 0.200 \\ 0.50 & 1060 & 0.160 & 145 & 0.190 \\ 0.60 & 1240 & 0.174 & 70 & 0.180 \\ 1.00 & 1300 & 0.220 & 0 & 0.140 \\ 2.00 & 1300 & 0.230 & 0 & 0.125 \\ & & * & & \end{array}$

Table 6. Purification of gamma haemolysin

\begin{tabular}{|c|c|c|c|c|c|}
\hline Purification step & $\begin{array}{l}\text { haemolysin } \\
\text { (h.u.) }\end{array}$ & $\begin{array}{l}\text { protein } \\
\text { (mg) }\end{array}$ & $\begin{array}{c}\text { Recovery } \\
(\%)\end{array}$ & $\begin{array}{c}\text { activity } \\
\text { (h.u./mg) }\end{array}$ & Purification \\
\hline Crude lysin & I5I 900 & $3844 \cdot 0$ & 100 & 40 & $\times I \cdot 0$ \\
\hline UItrafiltration & 148750 & 12140 & 98 & 123 & $\times 3 \cdot 1$ \\
\hline Gel filtration & 128000 & 198.9 & 84 & 643 & $\times 16 \cdot 3$ \\
\hline$\left(\mathrm{NH}_{4}\right)_{2} \mathrm{SO}_{4}$ fractionation & 107250 & $41 \cdot 7$ & 70 & 2572 & $\times 640$ \\
\hline Dialysis & II 5500 & $15 \cdot 8$ & 76 & 7333 & $\times 185.6$ \\
\hline $\mathrm{NaCl}$ extraction & II 5500 & $9 \cdot 8$ & 76 & II 737 & $\times 297.0$ \\
\hline$\left(\mathrm{NH}_{4}\right)_{2} \mathrm{SO}_{4}$ fractionation & 112450 & $I \cdot I$ & 74 & 108125 & $\times 2736 \cdot 0$ \\
\hline
\end{tabular}

haemolysin and protein (Table 5). All haemolytic activity was present in the precipitate when it was suspended in distilled water, but the addition of phosphate buffer caused some of the haemolytic activity to appear in the supernatant fluids. As the $\mathrm{NaCl}$ concentration was increased, more haemolysin dissolved and less activity remained in the precipitate. Although all haemolytic activity was recovered by the addition of $\mathrm{I} \cdot 0 \mathrm{M}-\mathrm{NaCl}, 45 \%$ of the protein was still insoluble. This $\mathrm{NaCl}$-extracted haemolysin contained protein but no phosphate or pentose.

Gamma haemolysin became unstable after $\mathrm{NaCl}$ extraction, all activity being lost after storage for $24 \mathrm{~h}$ at $4{ }^{\circ} \mathrm{C}$. If activity were to be retained, the haemolysin had to be preserved as a precipitate in ammonium sulphate solution. As a final step in the purification procedure, haemolysin was fractionated a second time with ammonium sulphate. The precipitate which formed after addition of the salt to $25 \%$ saturation was discarded and the haemolysin collected by further addition of ammonium sulphate to $60 \%$ saturation. The active material was washed once and stored in saturated ammonium sulphate solution. This last procedure increased the specific activity about ro-fold.

Table 6 summarizes the procedure developed for the purification of gamma lysin. The lysin was purified 2736 -fold with $74 \%$ recovery. Specific activity of the final product was $10^{5}$ h.u./mg protein.

Sedimentation velocity analyses of gamma lysin, electrofocusing and determination of 
the $N$-terminal amino acid have also been used as criteria of homogeneity and are described in the following paper (Fackrell \& Wiseman, 1976).

\section{Criteria of purity}

Purified gamma lysin showed a single peak $(4.3 \mathrm{~cm}$ from the origin, in the direction of the cathode) on polyacrylamide disc gel electrophoresis when $100 \mu \mathrm{g}$ dry wt material was applied to the column. Immunoelectrophoresis of the lysin showed a single line of precipitation near the anode when the lysin was diffused against antibody to crude material.

\section{DISCUSSION}

This study has shown that growth and production of gamma haemolysin by the Smith $5 R$ strain of $S$. aureus are not affected to the same degree by changes in $\mathrm{pH}$ or $\mathrm{CO}_{2}$ tension. These findings resemble those obtained with the alpha, beta and delta lysins, except that delta lysin production depends less upon the presence of $\mathrm{CO}_{2}$ (Wiseman, 1970). It has not been possible to replace the $\mathrm{CO}_{2}$ requirement of strain $5 \mathrm{R}$ with incubation of the cultures at acidic $\mathrm{pH}$ values, which indicates that lowering of $\mathrm{pH}$ is not an explanation of the $\mathrm{CO}_{2}$ requirement.

Our work has shown that gamma lysin is formed by the Smith $5 \mathrm{R}$ strain in the late exponential phase of growth and released into the medium. Although some lysin was found intracellularly, the bulk of it was extracellular at a time when autolysis was not appreciable.

The method of purification presented in this investigation has yielded gamma lysin purified 2700 -fold with $75 \%$ recovery. The specific activity of $10^{5} \mathrm{~h} . \mathrm{u} . / \mathrm{mg}$ protein is about I00 times greater than that of the preparation of Guyonnet \& Plommet (1970). These authors obtained evidence for two synergistic fractions of gamma lysin, each of which contained at least two other proteins. We were unable to confirm their findings with the same Smith 5R strain. It may be that their two fractions were contaminated with beta and delta lysins which are known to act synergistically (Elek, 1959). Mollby \& Wadstrom (1971) devised a method of purification of the gamma lysin based on ion exchange chromatography and isoelectric focusing. However, there is little or no evidence that their preparation was homogeneous.

This work was supported by the University of Manitoba and the Medical Research Council of Canada.

\section{REFERENCES}

BIRCh-HIRSChfELD, L. (1934). Über die Wirksamkeit der Extrakte von auf Zellophanagar gezüchteten Staphylokokken. Zeitschrift für Immunitätsforschung und experimentelle Therapie 81, 260-285.

Campbell, D. H., Garvey, J. S., Cremer, N. E. \& Sussidorf, D. H. (1970). Methods in Immunology, 2nd edn. New York: Benjamin.

Dolman, C. E. \& Wilson, E. J. (1940). The kitten test for Staphylococcus enterotoxin. Canadian Public Health Journal 31, 68-71.

ELEK, S. D. (1959). Staphylococcus pyogenes and its Relation to Disease. Edinburgh: Livingstone.

FACKRell, H. B. (1974). Studies with Gamma Hemolysin of Staphylococcus aureus. Ph.D. thesis, University of Manitoba, Winnipeg.

Fackrell, H. B. \& Wiseman, G. M. (1976). Properties of the gamma haemolysin of Staphylococcus aureus 'Smith 5R'. Journal of General Microbiology 92, 1 1-24.

Gladstone, G. P. \& Van Heyningen, W. E. (1957). Staphylococcal leucocidins. British Journal of Experimental Pathology 38, 123-137.

Gomor, G. (1955). In Methods in Enzymology, vol. I, pp. 138-146. New York: Academic Press.

GuYonnet, F. \& Plommet, M. (1970). Hemolysine gamma de Staphylococcus aureus: purfication et proprietés. Annales de l'Institut Pasteur 1r8, 19-23.

JACKson, A. W. (1962). Staphylococcal gamma lysin and its differentiation from delta lysin. VIIIth International Congress of Microbiology Abstracts, p. 111. 
MARKHAM, R. (1942). A steam distillation apparatus suitable for micro-Kjeldahl analysis. Biochemical Journal 36, 790-79I.

MARKS, J. (195I). The standardization of staphylococcal alpha-antitoxin, with special reference to anomalous hemolysins including delta-lysin. Journal of Hygiene 49, 52-66.

MolLBY, R. \& WADSTROM, T. (197I). Separation of gamma hemolysin from Staphylococcus aureus Smith 5R. Infection and Immunity $3,633-635$.

Plommet, M. \& Boulllanne, C. (1966). Production des hemolysines staphylococciques delta et gamma. Annales de Biologie Animale, Biochimie et Biophysique 6, 529-532.

SMrth, M. L. \& PrICE, S. A. (1938). Staphylococcus gamma hemolysin. Journal of Pathology and Bacteriology 47, 379-393.

StolP, H. \& Petzold, H. (1962). Untersuchungen über einen obligat parasitischen Mikroorganismus mit lytischer Activität für Pseudomonas-Bakterien. Phytopathologische Zeitschrift 45, 364-390.

Wiseman, G. M. (1970). In Microbial Toxins, vol. 3, pp. 237-263. New York: Academic Press.

WISEMAN, G. M. \& CAIRD, J. D. (1972). Further observations on the mode of action of the alpha toxin of Staphylococcus aureus 'Wood 46'. Canadian Journal of Microbiology 18, 987-992.

Wiseman, G. M., Carro, J. D. \& Fackrell, H. B. (1974). Trypsin-mediated activation of the alpha hemolysis of Staphylococcus aureus 'Wood 46'. Journal of Medical Microbiology 8, 29-38. 